\title{
DIPLOMASI DUA BUDAYA: STUDI KASUS PERBANDINGAN STRATEGI DIPLOMASI POP CULTURE KOREA SELATAN DAN JEPANG DI INDONESIA
}

\author{
Fidian Putri, Indrawati \\ Universitas 17 Agustus 1945 Jakarta
}

fidianp18@gmail.com, in.indrawati17@gmail.com

\begin{abstract}
ABSTRAK
Penelitian ini menggambarkan tentang perbandingan strategi diplomasi pop culture yang dilakukan oleh Korea Selatan dan Jepang. Pembahasan difokuskan pada pelaksanaan strategi Korean Wave dan Cool Japan dalam menyebarkann industri hiburannya ke berbagai negara di dunia termasuk di Indonesia, yang bertujuan untuk meningkatkan pertumbuhan ekonomi, walaupun pada awalnya hanya untuk menaikkan citra positif negara di mata dunia.

Metode penelitian yang digunakan dalam proses penyusunan skripsi ini adalah metode deskriptif komparatif. Sedangkan teknik pengumpulan data yang digunakan berdasarkan data primer dalam bentuk situs resmi pemerintah maupun surat kabar nasional dan internasional yang mengungkapkan hasil wawancara, dan data sekunder dalam bentuk telaah pustaka (library research), yaitu dengan mengumpulkan seluruh data dari berbagai literatur yang telah diperoleh dari beberapa tempat penelitian, seperti buku, majalah, surat kabar harian, artikel ilmiah, situs internet, jurnal, dokumen, perjanjian dan makalah ilmiah, yang berkaitan langsung mengenai permasalahan.

Hasil penelitian ini menunjukkan bahwa Korean Wave dan Cool Japan mengekspansi industri hiburan yang mengandung nilai-nilai kebudayaan Korea dan Jepang dengan bantuan aktor-aktor dari negaranya, seperti pemerintah, swasta atau pebisnis, dan media. Aktor-aktor tersebut memiliki berbagai strategi yang membawa pengaruh terhadap perkembangan industri hiburan kedua negara.

Kata kunci : Korean wave, cool Japan, diplomasi budaya
\end{abstract}

\section{ABSTRACT}

This research describes about the comparison of Pop Culture Diplomacy Strategy which conduct by South Korea and Japan. This Explanation focused on The Strategy Implementation of Korean Wave and Cool Japan at spreading the Entertainment to country all around the world including Indonesia. This phenomenon had a goal to expand the economic rate even though for the first, it just for the positive imaging in the world.

The Research Methodology had used is comparative descriptive. The Data collection based on the primary data in government official site, national and international newspaper which have a data related to interview. The seconder data is library research by gathering whole data from several literature which got 
by some research spot. They're such as book, magazine, newspaper, science article, internet site, journal, document, the agreement, and Science Paper which have a correlation to the subject research.

The result of this research shows the Korean Wave and Cool Japan had expanded the entertainment industry which have the culture value of Korea and Japan through the figure of actor from their own country. They're such as Government, entrepreneur and even the businessman and also media. Those actors have several strategy which take the influence of the entertainment on those countries.

Keywords: Korean Wave, Cool Japan, Culture Diplomacy

\section{Latar Belakang Masalah}

Seiring berkembangnya zaman, praktek diplomasi mengalami perubahan dari hard power menjadi soft power yang mengikuti dinamika dalam hubungan internasional. Diplomasi budaya yang di praktekkan oleh suatu negara merupakan diplomasi yang mengedepankan soft power, sehingga bisa dikatakan kekuatan sosial dan budaya memiliki peluang serta harapan untuk dapat mewujudkan kepentingan negara.

Pop Culture yaitu singkatan dari popular culture yang berarti budaya populer merupakan salah satu efek dari terjadinya fenomena globalisasi dalam aspek kebudayaan, salah satunya dengan tumbuhnya pop culture. Berbagai respon negatif pada dasarnya sempat bermunculan, karena globalisasi dalam konteks ini cenderung dianggap sebagai fenomena Amerikanisasi karena Amerika sebagai produsen terbesar dari kebudayaan populernya.

Pop culture merupakan salah satu bentuk dari diplomasi budaya yang dapat menjadi sarana untuk memperkenalkan kebudayaan suatu negara kepada dunia, sehingga dapat membentuk citra negara di mata dunia internasional dan membuat hubungan antar negara menjadi lebih erat dan intens. Pop culture pun menjadi alat untuk mewujudkan kepentingan suatu negara, yaitu dapat terlihat dari pop culture yang menjadi komoditas ekspor, seperti yang dilakukan oleh Korea Selatan dan Jepang.

Fenomena budaya populer Korea atau Korean Wave atau Hallyu berhasil membuat Korea Selatan menunjukan taringnya kepada dunia dan menaikkan citranya. Produk-produk kreatif tersebut memberikan tawaran inovasi baru bagi industri hiburan, yang mencakup film dan drama televisi, musik pop, animasi, lifestyle dan sejenisnya. Kini negara dengan sebutan negara gingseng tersebut mampu menjadi negara industri hiburan yang berbagai macam produknya terkenal diseluruh mancanegara, dimana sebelumnya Korea Selatan dikenal hanya sebagai negara industri. 
Hallyu yang berarti Korean Wave (arus gelombang budaya Korea) adalah sebuah fenomena dimana terjadi peningkatan popularitas dari kebudayaan Korea Selatan yang digemari oleh orangorang di Korea Selatan sendiri kemudian berkembang ke dunia internasional. Hallyu mengacu pada penyebaran budaya Korea Selatan di seluruh dunia atau kecintaan terhadap ekspor budaya Korea Selatan itu sendiri. Berkembangnya Hallyu di Indonesia berawal dari munculnya drama seri Korea terlaris kala itu yaitu Endless Love pada tahun 2002 di salah satu stasiun televisi swasta.

Belakangan ini tidak bisa dipungkiri bahwa produk-produk Korea Selatan telah menyebar di kalangan generasi muda, tak terkecuali di kalangan remaja Indonesia. Meniru gaya berpakaian artis-artis Korea merupakan tren bagi remaja di Indonesia. Tidak hanya itu, aliran musik dan drama di Indonesia mulai berkiblat ke Korea Selatan karena dinilai memiliki nilai jual yang tinggi. Dimulai dari tahun 2008 sampai pada sekarang ini sudah banyak boyband / girlband asal Korea Selatan yang melakukan konser di Indonesia. Makanan-makanan khas Korea juga mulai banyak diperjual-belikan di Indonesia. Selain itu, sekarang ini sudah banyak juga lembaga-lembaga kursus yang membuka kelas Bahasa Korea, bahkan beberapa universitas di Indonesia juga sudah mulai membuka jurusan Bahasa Korea, setelah sebelumnya didominasi oleh Jepang dan Mandarin.

Keberhasilan Korea Selatan menjadi negara industri hiburan yang terkenal seperti sekarang ini, demam akan budaya Jepang sudah terlebih dahulu merajai dunia hiburan mancanegara. Hampir disetiap negara mengenal akan kebudayaan Jepang, baik yang tradisional maupun yang modern. Penyebaran budaya populer Jepang telah menyebar ke berbagai seluruh belahan dunia dan berhasil menaikkan citra Jepang. Langkah Jepang untuk memasifkan promosi budaya populer secara global dan terstruktur itu disebut Cool Japan.

Budaya populer Jepang sudah tersebar ke berbagai negara sejak 1960-an, namun kesadaran pemerintah Jepang akan potensi budaya populernya baru muncul pada tahun 2000-an setelah seorang jurnalis asing, Douglas McGray, menyebut Jepang sebagai negara cultural super power. Dari artikel itu pula istilah Cool diperoleh. McGray menyebut Jepang saat itu bukan sebagai negara yang kaya secara ekonomi, tetapi secara budaya.

Setelahnya pemerintah Jepang berusaha memanfatkan popularitas budaya populer secara global untuk diplomasi budaya dan diplomasi publiknya untuk membentuk image baik Jepang di 
mata dunia sebagai negara yang damai dan kaya akan budaya. Baru dalam perkembangannya, pemerintah Jepang juga memanfaatkannya untuk perekonomiannya.

Pola-pola dari kebudayaan populer Korea Selatan dan Jepang tidaklah jauh berbeda, yaitu seperti musik, film, drama televisi, tarian pop, makanan dan gaya berpakaian yang mulai diperkenalkan kepada dunia sejak tahun 1990-an. Korea Selatan dan Jepang memanfaatkan kebudayaan sebagai perpanjangan agenda kepentingan yang ingin mereka capai, salah satunya dari bidang ekonomi agar menaikan devisa negara mereka.

Selain aktor yang berperan penting dalam melaksanakan diplomasi budaya, alat juga diperlukan sebagai hal penunjang untuk membantu penyebaran informasi. Alat yang digunakan disini adalah media, media merupakan alat yang penting dalam pelaksanaan diplomasi budaya. Melalui media yang canggih dan selalu update akan hal baru, produk dari budaya populer dapat tersebar keseluruh negara dibelahan dunia.

Dalam melakukan praktek diplomasi budaya, Korea Selatan dan Jepang memilih Indonesia sebagai salah satu negara tujuan untuk memasarkan produk-produk budaya mereka. Sifat masyarakat Indonesia yang konsumtif dan modern karena telah terpengaruh oleh globalisasi, membuat Korea Selatan dan Jepang dengan mudah menyodori produk-produk budaya mereka kepada masyarakat Indonesia sehingga mempunyai daya magnet tersendiri bagi masyarakat Indonesia, terutama kaum remaja. Remaja Indonesia melihat keunikan dari budaya Korea Selatan dan Jepang yang masuk kedalam negeri sehingga membuat para remaja tergila-gila akan K-Pop atau J-Pop.

Jika dilihat dari penelitian terdahulu, fokus penelitian yang dilakukan oleh peneliti-peneliti sebelumnya hanya sebatas satu pihak, yaitu penelitian mengenai diplomasi budaya atau diplomasi publik Korea Selatan, atau penelitian mengenai diplomasi budaya atau diplomasi publik Jepang. Maka dari itu, hal tersebut yang mendasari penulis untuk melakukan analisa lebih dalam mengenai perbandingan strategi diplomasi pop culture Korea Selatan dan Jepang. Dari penelitian ini akan terlihat negara mana yang lebih dominan atau lebih berhasil dalam menerapkan diplomasi publik sehingga terlihat dampak yang signifikan bagi negara tersebut.

\section{Kerangka Teori dan Konsep}

\section{Pop Culture}


Popular culture atau pop culture adalah budaya populer yang merupakan hasil dari globalisasi, seiring dengan perkembangan zaman membuat perubahan budaya tersebut menjadi semakin nyata. Dalam budaya populer, unsur-unsur dinamis dari budaya terlihat secara jelas, budaya adalah tatanan kehidupan yang di dalamnya manusia membangun makna melalui praktik-praktik representasi simbolik. Budaya dalam konteks budaya populer perlu dipahami secara dinamis, yakni sebagai serangkaian ide, reaksi dan ekspektasi yang berubah secara konstan saat orang-orang atau kelompok-kelompok itu sendiri berubah.

Istilah budaya populer (biasa disingkat sebagai budaya pop, atau dalam bahasa Inggris popular culture atau disingkat pop culture) mengandung berdebatan oleh para kritikus dan teoretisi budaya. Istilah budaya populer sendiri dalam bahasa Latin merujuk secara harfiah pada "culture of the people" (budaya orang-orang atau masyarakat). Kata "populer" dalam budaya populer dengan demikian bermakna tersebar luas, arus utama, dominan atau sukses secara komersial

\section{Diplomasi Publik}

Diplomasi adalah sebuah sistem komunikasi antarnegara dan resolusi atas sebuah permasalahan ataupun isu. Diplomasi diartikan sebagai proses dialog dan akomodasi antar negara untuk menanggapi sebuah peluang (S Rana, 2011). Pengertian ini merujuk pada makna government to government dan diplomasi dalam arti tersebut masih bermakna diplomasi tradisional.

Pada perkembangannya praktek diplomasi tidak hanya sekedar aktor pemerintah yang berkontribusi, melainkan juga terdapat aktor non-pemerintah yang ikut serta dalam diplomasi. Hal tersebut berkaitan dengan munculnya isu-isu baru dalam hubungan internasional serta beragamnya kepentingan nasional setiap negara. Sehingga jika hanya menggunakan diplomasi tradisional dirasa kurang efektif dalam menjawab isu-isu yang baru, karena pemerintah dianggap tidak selalu dapat menjawab atau menyelesaikan permasalahan diplomasi pada isuisu baru tersebut.

Diplomasi publik menurut Mark Leonard terbagi menjadi tiga dimensi berdasarkan pada kebutuhan spesifik dengan skenario berbeda. Dimensi tersebut adalah reaktif, proaktif dan membangun hubungan (relationship building) yang dapat diarahkan ke bidang politik atau 
militer, ekonomi atau sosial budaya bahkan kombinasi dari bidang-bidang tersebut. Dalam mencapai tujuan diplomasi publik pemerintah tidak hanya memahami satu dimensi saja, tetapi juga harus mampu memahami ketiga dimensi tersebut agar dapat melengkapi satu dengan lainnya sehingga makna dapat tersampaikan dengan benar.

\section{Multi Track Diplomacy}

Multi-track diplomacy telah menjadikan diplomasi bukan hanya tugas diplomat professional ataupun pemerintah dalam pengertian umum, namun merupakan sebuah upaya untuk merangkul dan melibatkan masyarakat dari berbagai negara dalam suatu hubungan yang harmonis guna mewujudkan persahabatan bangsa-bangsa menuju perdamaian dunia. Selain itu pula, di era globalisasi hubungan antar negara yang terjalin kini semakin dimudahkan karena ke delapan track disatukan oleh memanfaatkan kecanggihan teknologi komunikasi dan informasi.

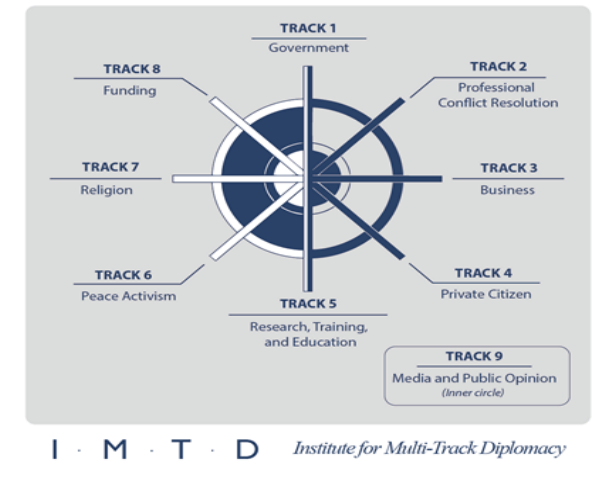

dunia hingga peacebuilding yang terintegrasi satu sama lain menggunakan soft power.

\section{Pembahasan}

\section{Sejarah Korean Wave dan Cool Japan}

Popular culture atau pop culture adalah budaya populer yang merupakan hasil dari globalisasi, seiring dengan perkembangan zaman membuat perubahan budaya tersebut menjadi semakin nyata. Dalam budaya populer, unsur-unsur dinamis dari budaya terlihat secara jelas, budaya adalah tatanan kehidupan yang di dalamnya manusia membangun makna melalui praktik-praktik representasi simbolik (Ibrahim, 2007, hal. 21). Budaya dalam konteks 
budaya populer perlu dipahami secara dinamis, yakni sebagai serangkaian ide, reaksi dan ekspektasi yang berubah secara konstan itu sendiri berubah (Ibrahim, 2007).

Pop culture ini terdiri dari film, musik, acara televisi, surat kabar, makanan, pakaian, halhal yang berhubungan dengan dunia dan menjadi bagian dari masyarakat. Dijelaskan secara lebih lanjut oleh salah satu sosiologi, Peter Berger bahwa pop culture membawa keyakinan dan nilai-nilai yang sangat signifikan. Ia memberikan contoh dalam hal ini musik rock. Daya tarik yang dimiliki oleh jenis musik ini pada dasarnya tidak hanya karena musiknya yang keras, suaranya yang berirama dan dengan tarian yang cenderung keras, tetapi jenis music ini juga menggambarkan nilai-nilai budaya seperti kebebasan berekspresi, spontanitas, dan juga pembebasan dari kehidupan yang membosankan (Culture and Globalization,www.globalization101.org/uploads/File/Culture/cultall2010.pdf diakses 31/3/2018).

Terjalinnya hubungan antar negara-negara di dunia menjadi lebih luas dan lebih dekat merupakan sebuah proses dari globalisasi. Globalisasi bukan hanya permasalahan ekonomi, politik, ataupun masalah keamanan. Globalisasi telah masuk ke dalam seluruh aspek kehidupan sosial dan budaya manusia. Sadar akan fenomena ini, pemerintah Korea Selatan dan Jepang dengan cerdas mempromosikan budaya mereka yang bernama Hallyu (Korean Wave) dan Cool Japan ke dunia global dengan tujuan untuk meningkatkan daya tarik masyarakat internasional.

\section{Sejarah Korean Wave (Hallyu)}

Seorang jurnalis China pada akhir tahun 1990an melihat suatu fenomena baru di China, tentang kegemaran masyarakat China terhadap produk-produk Korea yang notabene adalah Korea Selatan. Kontribusi paling besar pada kelahiran Korean Wave adalah dari bidang drama dan film. Pada saat itu film seri Korea yang berjudul "What on Earth is Love" yang ditayangkan sampai di saluran televisi China, dan disaksikan oleh lebih dari 39 juta pecinta drama Korea di China (Raditya, 2013). Disusul dengan keberhasilan serial drama "Winter Sonata" yang menaklukkan pasar Jepang pada tahun 2003 (Wibowo, 2013).

Kegemaran akan Korea ini dimulai dengan masuknya yang sampai sekarang sudah meluas ke Asia Tenggara dan Amerika. Tidak salah lagi kegemaran akan budaya pop ini menjadi 
pemicu utama digemarinya produk-produk Korea, begitu juga dengan fashion, makanan dan model penampilan para bintang-bintang Korea (Passport to Korean Culture, 2010).

Hán liú (韓流), begitu China memberikan nama kepada fenomena ini, yang akhirnya disebut dengan Hallyu (한류) (menyesuaikan dengan sebutan di Korea). Hallyu sendiri berarti Korean (Cultural) Wave/Current (arus gelombang budaya Korea). Fenomena ini menjelaskan adanya suatu fenomena perkembangan budaya Korea Selatan ke dunia Internasional. Hallyu yang pada awalnya hanya berupa kegemaran akan budaya pop Korea, semakin melebar menjadi kegemaran akan serial drama Korea. Sampai saat ini, Hallyu diikuti dengan banyaknya perhatian akan produk Korea Selatan, seperti masakan, barang elektronik, musik, dan film. Fenomena ini turut Korea ke berbagai negara (Passport to Korean Culture, 2010).

Kebangkitan drama Korea merupakan buah dari demokratisasi yang dimulai akhir 1980, sejak rezim otoriter Korea tidak berkuasa ada kemerdekaan yang membuat film atau drama tanpa terkukung kreativitasnya. Walaupun Korea masih terpecah antara Korea Selatan dan Korea Utara, pemerintah tidak menekan media untuk menjadi agen propaganda. Tingkat independensi media massa tercatat menduduki urutan ke-21 dunia.

Perkembangan penyebaran drama Korea mulai terlihat semakin besar sejak tahun 2010. Kebesaran ini terlihat dari status Korea Selatan sebagai urutan ke sembilan dunia dalam pangsa pasar film, dan menjadi negara paling besar belanjanya untuk pertunjukkan dan film. Hal ini karena terus meningkatnya kepopularitasan industri tersebut, yang mengandung cerita, teknologi, akting dan lokasi yang semuanya terpadu dengan sangat baik, apik serta menarik.

Drama Korea dikatakan memiliki sensasi yang berbeda dari apa yang dimiliki Hollywood, dikarenakan drama Korea memiliki ciri-ciri dan sentimen Korea yang kuat yang mana kebanyakan dapat dengan mudah memahami dan menyerapnya (Yudhantara, 2010). Misalnya, film Korea yang berjudul "Shiri" telah menjadi populer di Jepang, Hongkong, dan Taiwan yang mampu mengalahkan "Titanic" dengan 4,7 juta penonton, sedangkan "Shiri" dengan 5,78 juta penonton (Cine21, https://www.cine21.co.kr, diakses 31/3/2018).

Hal tersebut sempat mengejutkan Hongkong, dikarenakan pada awal tahun 1990-an Korea masih belajar tentang membuat film yang baik di Hongkong, namun dalam waktu singkat Korea berhasil menjadikan industri perfilmannya menjadi salah satu komoditi ekspor yang 
utama di negaranya (Yudhantara, 2010). Pada tahun 1996 album musik pop band Korea H.O.T yang rilis di China pun tidak kalah diminati (Aziz, 2013).

Fashion Korea turut popular di Indonesia seiring dengan populernya Hallyu, seperti fenomena $\mathrm{K}$-Cut Style yang muncul di berbagai salon di Jakarta, salah satunya Johnny Andrean. Tidak hanya gaya rambut Korea yang popular, melainkan juga kosmetiknya. Populernya Hallyu mendorong kemunculan merek kosmetik, seperti The Face Shop, Etude, dan Nature Republic.

Populernya Hallyu di Indonesia membuat para penggemar bukan hanya sekedar mimpi untuk dapat bertemu dengan artis idolanya. Showcase menjadi salah satu kesempatan bagi para penggemar untuk dapat melihat idolanya secara langsung. Melihat perkembangan $K$-Pop di Indonesia membuat para produsen $K$-Pop tidak ragu untuk mengirim artisnya menjumpai penggemar Indonesia melalui berbagai acara.

Selain memang karena Korea Selatan memiliki alam yang sangat menawan, melalui sarana drama maupun musik video, pencitraan alam Korea Selatan pun semakin hebat. Tiap tahunnya mengalami peningkatan wisatawan yang datang mengunjungi Korea Selatan. Para wisatawan inu umumnya mengunjungi Pulau Nami yang merupakan tempat shooting drama Winter Sonata dan juga Pulau Jeju yang memiliki panorama yang sangat indah.

\section{Sejarah Cool Japan}

Pada akhir tahun 1990-an, Jepang harus mulai kembali mengubah strategi diplomasinya seiring dengan arus globalisasi yang memberikan tantangan-tantangan baru. Salah satu strategi yang digunakan oleh Jepang adalah untuk mengembangkan budaya-budaya modern, disamping memanfaatkan budaya-budaya tradisional yang telah ada sebelumnya.

Jepang benar-benar memanfaatkan pop culture sebagai sarana diplomasi, Jepang pun memaksimalkan hal tersebut dengan menciptakan sebuah konsep yang disebut dengan Cool Japan. Di mana konsep tersebut diciptakan agar masyarakat internasional dapat lebih mengenal dan tertarik dengan Jepang. Terbukti di mana langkah-langkah antisipasi yang bersifat non-formal tersebut ternyata berperan efektif di samping sebagai media diplomasi Jepang, juga hal tersebut dapat memberikan keuntungan dari sektor ekonomi. 
Budaya populer Jepang sudah tersebar ke berbagai negara sejak dekade 1960-an, tetapi potensi akan budaya populer tersebut baru disadari oleh pemerintah Jepang pada tahun 2000an setelah seorang jurnalis asing bernama Douglas McGray, menyebut Jepang sebagai negara cultural super power di dalam artikelnya. Dari artikelk itu pula istilah Cool diperoleh. McGray menyebut Jepang saat itu bukan.

Sebagai negara yang kaya secara ekonomi, tetapi secara budaya, bukan unggul dalam Gross National Product, tapi Jepang unggul dalam Gross National Coolness (Douglas McGray: Japan's Gross National Cool, http://foreignpolicy.com/2009/11/11/japans-grossnational-cool diakses 27/7/2018).

McGray mengatakan bahwa walaupun bruto nasional Jepang mengalami pengecilan, hal itu menjadi batu loncatan bagi "gross national cool". Mulai dari musik pop, konsumen elektronik, arsitektur sampai fashion, Jepang memiliki kekuatan kebudayaan di negaranegara lain.

Cool Japan adalah sebuah proyek yang memiliki tujuan untuk meningkatkan kesan positif terhadap Jepang melalui promosi Dalam penggunaannya secara luas, Cool Japan ini menjadi bagian dari kebijakan MOFA (Ministry of Foreign Affairs; Kementerian Luar Negeri Jepang) untuk promosi budaya populer Jepang. Namun, pada tahun 2011 pemerintah Jepang bergerak lebih jauh. Cool Japan diletakkan dalam asuhan METI (Ministry of Economy, Trade and Industry; Kementerian Ekonomi, Perdagangan dan Industri Jepang), yang berarti Jepang mempunyai agenda perekonomian terkait Cool Japan secara global (Kaori Nusantara, Kusumanto, https://www.kaorinusantara.or.id/newsline/23003/diskusi-ilmiahmengenal-cool-japan-asal-usul-perkembangan-dan-tujuan-strategi-ekonomi-kreatif-jepang diakses 30/5/2018).

Berkembangnya pop culture Jepang menjadikan beberapa negara mengikuti stylepop culture Jepang tersebut salah satunya adalah negara Indonesia. Berkembangnya budaya Jepang di Indonesia sendiri tidak terlepas dari peranan masuknya serial animasi (anime), komik (manga), musik, game, film, J-pop, drama, dan cosplay. Kehadiran manga di Indonesia semakin memperkenalkan Jepang kepada masyarakat. Manga yang merupakan sub-kultur semakin dikenal luas dan diminati oleh masyarakat Indonesia khususnya remaja. 
Bukan hanya manga saja adapula anime, banyak tayangan di Indonesia yang kini menyiarkan kartun-kartun asal Jepang seperti Naruto, Dragonball, Detective Conan, Samurai X, Sailormoon, Ghost Stories, Hamtaro, Doraemon dan lain sebagainya.

Penyebaran pop culture Jepang di Indonesia masuk pada tahun 1980-an melalui media televisi TVRI sebagai stasiun televisi Indonesia pertama dengan menayangkan anime yang berjudul (Wanpaku Omukasi Kum-Kum) setiap pukul $17.30 \mathrm{WIB}$, tetapi pada saat itu anime sempat tidak lagi ditayangkan karena keterbatasan media di Indonesia (Japanese Station, https://books.google.co.id diakses 28/7/2018.). Hingga pada tahun 1990-an manga mulai diproduksi oleh Indonesia dan anime mulai kembali di tayangkan dan menjadi sangat populer di Indonesia.

Selain anime dan manga yang populer di Indonesia, musik pop Jepang bentuk lain dari pop culture Jepang adalah J-pop (Japanese Pop Music), banyak remaja yang ikut mempelajari lagu Jepang. Masuknya budaya Jepang di Indonesia banyak yang menggangapi hal positif sebagai hobi, kegemaran, bahkan untuk mengekspresikan diri mereka, tetapi ada juga yang menyikapinya dengan berpendapat bahwa budaya Jepang ke Indonesia sebagai hal yang negatif, karena telah merusak budaya Indonesia sendiri.

\section{Dukungan Pemerintah Korea Selatan}

Pemerintah Korea Selatan konsisten dalam usahanya mempromosikan Korean Wave sebagai sarana soft diplomacy dalam rangka menciptakan citra Korea di mata internasional dan menaikkan perekonomian negara. Sekitar 20 tahun lalu, pemerintah Korea memberi beasiswa besar-besaran kepada para artis dari berbagai bidang seni untuk belajar di Amerika Serikat dan Eropa. Pemberian beasiswa ini bertujuan untuk meningkatkan pengetahuan para artis mengenai seni yang ditekuninya. Dengan memberikan beasiswa untuk belajar di negara-negara yang lebih berpengalaman dalam seni modern, yaitu Amerika Serikat dan Eropa, Pemerintah Korea saat itu mendorong para pelaku seni untuk meningkatkan kemampuan diri dalam berseni. Hasil dari beasiswa ini adalah munculnya berbagai artis seni yang berpengalaman (Shin, 2003). 
Pada tahun 1994, Presiden Kim Young-sam mengumumkan kebijakan segyehwa di Sydney Declaration of 17 November 1994. Segyehwa merupakan sebuah kebijakan yang muncul sebagai reaksi atas fenomena globalisasi yang mulai marak terjadi, terutama globalisasi ekonomi. Presiden Kim Young-sam melihat globalisasi sebagai sebuah jalan pintas bagi Korea untuk menjadi negara yang maju dan lebih baik (The Korean Times, 2013).

Segyehwa memiliki arti lebih dari sekedar liberalisasi ekonomi, karena istilah segyehwa yang dianggap sebagai kebijakan pembangunan nasional juga mencakup sosial, politik, ekonomi dan budaya, termasuk didalamnya militer, finansial, buruh, pendidikan, hukum, serta kesejahteraan. Presiden Kim Young-sam mengibaratkan segyehwa sebagai jawaban atas tantangan perubahan revolusioner yang terjadi di abad 20 (Al Aziz, 2013).

Tujuan dari segyehwa ini ada lima, yaitu untuk menjadikan Korea sebagai negara kelas dunia, merasionalisasi seluruh aspek kehidupan, menjaga kesatuan nasional dengan menghilangkan perbedaan antar kelas, memperkuat identitas nasional Korea sebagai basis untuk kesuksesan globalisasi, dan meningkatkan rasa kebersamaan dengan sesame manusia (Al Aziz, 2013).

Pada saat ini, dukungan Pemerintah Korea akan penyebaran Korean Wave dapat dilihat dari lembaga yang berada di bawah Kementerian Budaya Korea, yaitu Korean Cultural and Infromation Service (KOCIS). KOCIS sendiri berada di bawah Kementerian Budaya Korea, dan mulai berdiri pada Desember 1971 dengan tujuan untuk menaikkan citra nasional Korea (http://www.kocis.go.kr/ diakses 26/7/2018). Pada situs resmi KOCIS dapat dilihat bahwa Korea telah menyadari sejak lama mengenai pentingnya soft power, dimana salah satunya adalah budaya. Pada tahun 2009, KOCIS meluncurkan Korean Cultural Center (KCC) dan Culture and Information Officers ke seluruh dunia.

\section{Dukungan Pemerintah Jepang}

Secara resmi, program Cool Japan diluncurkan oleh Pemerintah Jepang dan mendapatkan dukungan dana pada tahun 2013 di bawah Cool Japan Fund Inc, program tersebut bernilai sebesar US\$500 juta dengan jangka waktu 20 tahun yang diproyeksikan 
untuk menumbuhkan ekonomi Jepang hingga $¥ 900$ triliun dalam bidang industri kebudayaan pada tahun 2020 (Atsuko Fukase: Tokyo Launches Cool Japan Investment Fund $\quad$ http://blogs.wsj.com/japanrealtime/2013/11/18/tokyo-launches-cool-japaninvestment-fund/ diakses 8/3/2019).

Pemerintah Jepang memberikan dukungan terhadap Cool Japan sebagai kebijakan penggunaan soft power, yaitu untuk menunjukkan bahwa Jepang adalah negara yang keren dalam hal hiburan. Dalam hal ini, pada awal tahun 2015, Pemerintah Jepang memberikan anggaran sebesar jutaan dolar Amerika Serikat kepada perusahaan bisnis Jepang yang memiliki pasar internasional, seperti online shop Tokyo Otaku Mode dan Ramen Ippudo (Patrick St. Michel: Japan's Ministry of Cool, http://www.theatlantic.com/entertainment/archive/2015/3/japan-and-the-power-ofcoolness/387664/ diakses 8/3/2019.

Pada awalnya pemerintah memberikan dukungan dan mempromosikan Cool Japan tidaklah berhubungan dengan artikel Foreign Affairs McGray. Awal mula munculnya kata content pada dokumen pemerintahan adalah pada General Policy Speech to the 150th Session of Diet di bulan September 2000 oleh Perdana Menteri Yoshiro Mori yang mengajukan sebuah Internet Exhibition untuk menstimulasi penyebaran internet (Mori, 2000).

Pada Juli 2002, dukungan pemerintah atas industri konten didiskusikan secara serius. Intellectual Property Strategy Outline yang disusun oleh Intellectual Property Council yang didirikan oleh kantor kabinet pada Juli 2002, mengajukan dukungan bagi kreasi konten yang cemerlang dan promosi perlindungan dan distribusi kreasi konten. Dalam General Policy Speech to the 156th Session of Diet pada Januari 2003, Junichiro Koizumi, Perdana Menteri dan Presiden partai Liberal Demokrat dari tahun 2001 sampai 2006 memberikan sebuah pidato.

Intellectual Property Headquarters mendirikan Working Group on Contents untuk mendiskusikan permasalahan-permasalahan mengenai promosi bisnis konten pada Oktober 2003 dan sembilan pertemuan yang diadakan pada tahun 2007. Di tahun 2004, markas tersebut mengeluarkan The Policy for Promotion of Content Bussiness: National 
Strategy in the Age of Soft Power. Hal itu memperdebatkan bahwa industri konten seharusnya menjadi pilar dari strategi nasional karena ukuran pasarnya, dampak ekonomi pada industri-industri lain dan kuatnya soft power.

Promosi konten Jepang ke luar negeri, khususnya bagi perusahaan kecil, didukung oleh Japan External Trade Organization, sebuah organisasi yang berada di bawah yurisdiksi METI. Kantor JETRO yang berada di Los Angeles mengeluarkan laporan The Status Quo and Prospects of the US Anime Market pada tahun 2003 yang menjadi laporan pertama JETRO mengenai ekspor konten dan semenjak itu teah dikeluarkan laporan yang sejenis di beberapa negara dan area, khususnya di Asia, Eropa dan Amerika Selatan. Pada tahun 2003, Divisi Media dan Industri Konten mendirikan Content Industry International Strategy Study Group, yang secara garis besar mendorong konten industri untuk menjadi industri pedoman yang baru untuk memanfaatkan ekonomi dan untuk berkontribusi meningkatkan nilai citra bangsa dalam aspek ekonomi dan aspek.

Global Strategy Study Group didirikan pada tahun 2006 untuk memeriksa perkembangan Content Industry Internaational Strategy Study Group. Laporannya dikeluarkan pada tahun 2007 yang mengajukan arahan-arahan bagi industri konten Jepang untuk mendunia. Salah satunya adalah Japan International Content Festival yang diselenggarakan pada tahun 2007 dan dikenal dengan sebutan "CoFesta". CoFesta merupakan sebuah festival yang memperkenalkan secara komprehensif konten-konten Jepang, seperti game, animasi, manga, broadcasting, musik, film, fashion dan desain selama satu bulan penuh. Acara-acara besar seperti Tokyo Game Show, Tokyo International Film Festival, dan Japan Fashion Week juga merupakan bagian dari festival ini.

Cool Japan lebih diutamakan lagi oleh Taro Aso, Menteri Kementerian Luar Negeri Jepang dari tahun 2005 sampai 2007, dan Perdana Menteri Jepang dan Presiden Partai Liberal Demokrat dari tahun 2008 sampai 2009 yang dikenal sebagai penggemar berat manga. Taro Ase membuat pidato yang berjudul "A New Look at Cultural Diplmoacy: A Call to Japan's Cultural Practitioners" pada Universitas Digital Hollywood pada tahun 2006 (Aso, 2006). 
Salah satu ide Aso adalah International MANGA Award yang didirikan pada tahun 2007 untuk menghargai mangaka (pencipta manga) non-Jepang yang berkontribusi untuk mempromosikan manga ke luar negeri. Pemenang penghargaan ini diundang pada sebuah upacara di Jepang dan bergabung dalam tur Jepang selama sepuluh hari, yang diatur oleh Japan Foundation, untuk mengunjungi legenda mangaka Jepang, perusahaan penerbit manga dan lain-lain.

Selain itu, di bawah pemerintahan Aso, dengan tujuan mengaitkan antara karya animasi dengan minat terhadap negara Jepang sendiri, karakter animasi Doraemon dilantik sebagai Duta Kebudayaan Animasi pada tahun 2008. Di waktu yang sama pula, pemerintah bekerja sama dengan perusahaan penerbitan dan film untuk menayangkan film berjudul Dinosaurus Doraemon dan Nobita tahun 2006 yang telah diterjemahkan ke dalam bahasa Inggris, Perancis, Spanyol, Mandarin, dan Rusia.

\section{Para Bintang Hallyu Dalam Diplomasi Budaya Populer Korea Selatan}

Para boyband atau girlband, penyanyi solo, aktor dan aktris termasuk ke dalam aktor dalam track kedua ini, mereka mempunyai andil besar dalam proses penyebaran Hallyu ke mancanegara. Para bintang Hallyu adalah aktor yang berdiri di posisi paling depan sebagai wajah Hallyu. Pada dasarnya mereka mereka memiliki peran utama dalam ekspansi kebudayaan Korea Selatan ke lingkungan internasional. Hal ini disebabkan popularitas yang telah lebih dahulu mereka dapatkan di berbagai negara di dunia sehingga memudahkan masuknya kebudayaan Korea Selatan.

Popularitas bintang Hallyu dinilai mampu mempengaruhi opini publik demi mencapai kepentingan nasional Korea Selatan. Para bintang Hallyu bersedia menerima setiap tawaran dari pemerintah maupun dari para chaebol untuk menjadi duta atau brand ambassador. Kemauan itulah yang menjadi dukungan dari para bintang Hallyu sebagai aktor yang ikut berperan dalam diplomasi budaya Korea Selatan.

Pada awal Oktober 2010 Shinee mengadakan konser di Jakarta saat diadakan Pekan Budaya Indonesia-Korea. Pada 11 November 2011, 2PM menggelar konser di JITEC Mangga Dua Square, Jakarta. Kemudian pada 4 Juni 2011 digelar lagi konser K-Pop 
bernama KIMCHI (Korean Idols Music Concert Hosted in Indonesia) di Istora Senayan, Jakarta (Susanthi, 2011). Pada tahun 2012, banyak diadakan pula acara-acara K-Pop di Indonesia, salah satunya yakni pada Maret diadakan K-Pop Gathering "Tribute to Super Junior" dalam rangka menyambut konser Super Show 4 Super Junior pada 27 sampai 29 April 2012 di Mata Elang Indoor Stadium Ancol, Jakarta. Pada 22 September 2012, RCTI menayangkan konser artis-artis Korea bernama SM Town Live World Tour III di Stadion Gelora Bung Karno, Jakarta (Susanthi, 2011).

Pada tahun 2013, artis-artis Korea banyak yang mengadakan konser di Indonesia, seperti SNSD, Super Junior, 2PM, Shinee, Beast (sekarang Highlight), Infinite, Teen Top, dan Eru. Selain itu ada pula Lee Min Ho, actor yang berperan dalam K-Drama Boys Before Flowers, CN Blue, dan juga G-Dragon yang turut datang ke Indonesia di tahun 2013.

Secara tidak langsung, tidak bisa ditampik bahwa hal ini dapat menarik minat fans dari artis tersebut untuk mengunjungi tempat yang telah dikunjungi idolanya (Prasetiya Mulya Tourism, http://prasmultourism.com/2017/11/01/cara-korea-selatan-memajukanindustri-pariwisata/ diakses 29/7/2018). Belum lagi sejumlah lokasi syuting drama korea tidak lepas dari perhatian Pemerintah Korea Selatan untuk mengembangkannya menjadi tempat wisata. Sebut saja lokasi syuting di Phoenix Park pada drama Autumn in My Heart di Indonesia lebih dikenal dengan Endless Love kini menjadi tempat wisata favorit. Atau lokasi syuting serial Winter Sonata yang berlokasi di Pulau Nami, sekitar $63 \mathrm{~km}$ dari ibu kota Seoul sampai kini masih ramai dikunjungi oleh wisatawan.

\section{AKB48 Dalam Diplomasi Budaya Populer Jepang}

Fenomena berkembangnya budaya populer Jepang di Indonesia tidak terlepas dari antusiasme masyarakat Indonesia terhadap kegiatan-kegiatan promosi kebudayaan Jepang di Indonesia seperti Jak-Japan Matsuri, dan World Cosplay Summit. Selain itu tingginya minat terhadap film kartun Jepang dan komik-komik Jepang serta adaptasi dari hal tersebut menjadi indikasi diterimanya budaya Jepang di Indonesia. Salah satu instrumen diplomasi publik Jepang melalui kebudayaan di Indonesia adalah AKB48. Hal 
ini dibuktikan dengan dibentuknya Sister Group pertama AKB48 di luar Jepang yaitu JKT48. AKB48 merupakan grup yang kental terhadap unsur-unsur budaya populer Jepang, diantaranya adalah kostum, musik, dan gaya hidup.

AKB48 tidak terlepas dari upaya pemerintah Jepang dalam mengembangkan diplomasi publiknya. Hal ini seperti yang tercantum dalam Diplomatic Bluebook Jepang tahun 2004. Dalam buku tersebut dijelaskan bahwa Pop Culture dimasukkan ke dalam Diplomatic Bluebook pada tahun 2004 dengan program “Cool Japan”. Pop Culture menurut Diplomatic Bluebook adalah suatu instrumen yang dapat digunakan untuk menarik perhatian masyarakat internasional terutama anak-anak muda, dimana AKB48 termasuk ke dalamnya (http://scholar.unand.ac.id/38566/4/BAB\%20I.pdf diakses 1/3/2019).

Sebagai bukti, AKB48 terlibat dalam kegiatan promosi kebudayaan Jepang di dunia internasional. Pertama ketika AKB48 membantu pemerintahan Jepang dalam menggalang dana untuk daerah korban gempa Tohoku melalui proyeknya "Dareka No Tameni" dan penjualan single berjudul "Kaze Wa Fuiteiru" (The Daily Japan, Pop Culture: Revitalisasi Pengaruh Internasional Jepang, 1/3/2019). Kegiatan kedua adalah pemerintah Jepang memilih AKB48 sebagai Goodwill Ambassadors ke Tiongkok, Menteri Luar negeri Jepang pada saat itu memilih AKB48 sebagai salah satu upaya untuk meredakan ketegangan di antara kedua negara dengan cara mempromosikan budaya populer Jepang melalui AKB48 yang tampil di Tiongkok (The Daily Japan, Pop Culture: Revitalisasi Pengaruh Internasional Jepang, https://the-dailyjapan.com/pop-culturerevitalisasi-pengaruh-internasional-jepang diakses pada tanggal 1/3/2019).

Kegiatan ketiga adalah pada tanggal 14 Desember 2013 pada saat jamuan makan malam para tamu KTT ASEAN-Jepang di Tokyo, ketika itu setelah presentasi promosi kebudayaan Jepang AKB48 tampil dan membawakan dua buah lagu di hadapan para tamu (Japanese Station: AKB48 Mewakili Budaya Jepang Pada Gala Perjamuan ASEAN, https://japanesestation.com/akb48-mewakili-budaya-jepang-pada-gala-perjamuanasean/ diakses 1/3/2019). 
"Berbagai kegiatan yang telah dilakukan AKB48 bersama pemerintah Jepang telah membuktikan bahwa AKB48 juga merupakan aktor non pemerintah yang bisa melakukan diplomasi budaya populer Jepang dan memiliki pengaruh di dunia internasional. Hal ini sesuai dengan tulisan Mark Leonard, dimana terdapat beberapa pihak yang dapat menjadi aktor diplomasi yaitu, $N G O$, Diaspora, Partai politik, dan Merek dagang (Leonard, 2002). AKB48 termasuk ke dalam kategori merek dagang yang melakukan upaya promosi kepentingan nasional Jepang dengan mempengaruhi masyarakat di luar negeri.

Melalui produk-produk budaya populer ini Jepang baik secara langsung ataupun secara tidak langsung telah memperkenalkan nilai-nilai serta budaya Jepang seperti bahasa, tarian, musik dan fashion. Tidak hanya itu fenomena AKB48 di Indonesia juga turut mempengaruhi interaksi antara individu dan kelompok dari kedua negara. Hal ini menjadi sesuatu yang baru di Indonesia terutama dalam hal industri musik. Kondisi ini menjadi dasar untuk melihat diplomasi publik Jepang melalui instrumen budaya populer di Indonesia.

\section{Perusahaan Agen Hiburan Korea Selatan}

Disamping pemerintah, para pengusaha dan chaebol (pemilik bisnis raksasa/konglomerat) yang turut membantu mempromosikan Korean Wave. Para chaebol memberikan bantuan dana untuk memajukan perfilman Korea Selatan yang sempat macet karena kurangnya dana. Tidak hanya dalam bidang perfilman, chaebol juga membantu penyebaran Korean Wave dalam bidang musik pop Korea. Salah satu perusahaan besar yang bergerak dalam bidang teknologi, turut mendukung konser salah satu grup K-pop pada tahun 2012, "Bigbang global Tour Concert" yang disponsori oleh Samsung (CNBN, 2014).

Pihak swasta lain yang sangat berpengaruh terhadap penyebaran Korean Wave adalah pelaku industri profesional bidang hiburan Korea Selatan. Aktor yang yang berperan penting terhadap awal mulanya terbentuknya Korean Wave adalah pelaku industri profesional yaitu perusahaan hiburan. Dalam penyebaran Korean Wave, dimulai 
dari tahap planning, casting, training, assesment, producing, dan promotion calon artis Korea yang dilakukan oleh para pelaku industri profesional.

Tiga perusahaan agen hiburan yang terbesar dalam industri budaya Korea Selatan adalah SM Entertainment yang telah menghasilkan grup musik H.O.T pada awal penyebaran Korean Wave. Lalu ada JYP Entertainment, dan YG Entertainment. Ketiga perusahaan tersebut telah menerbitkan banyak artis idola yang tidak hanya sukses di dalam Korea, namun juga di luar Korea dengan populeritas yang mendunia (Korean Culture and Information Service, Korean Culture No.2, 2011).

\section{Manajemen Kerajaan Idol Grup 48 Akimoto Yasushi}

Tidak jauh berbeda dengan apa yang dilakukan oleh Korea Selatan, dalam melakukan diplomasi budaya pop Jepang juga memainkan aktor diluar pemerintah. Aktor dalam hal ini adalah seorang public figure, dibalik kesuksesan public figure pasti ada sebuah manajemen yang mengelola produknya tersebut hingga laku di pasar industri hiburan. Yang kemudian dari manajemen tersebut munculnya ide bisnis untuk memperluas jangkauan bisnisnya. Di track tiga ini dalam dukungan swasta atau pebisnis Jepang, penulis mengambil contoh manajemen AKB48.

AKB48 adalah idol grup asal Jepang yang telah terkenal di dunia. AKB48 dibentuk oleh Akimoto Yasushi pada tahun 2005 di Akihabara, Jepang. Lalu Akimoto mulai membentuk Sister Group (adik) dari AKB48 di Jepang yaitu SKE48 pada tahun 2008 di Sakae, Nagoya; SDN48 (sudah dibubarkan) pada tahun 2009; NMB48 pada tahun 2011 di Namba, Osaka; dan HKT48 pada tahun 2011 di Hakata, Fukuoka (Asian Fans Club: JKT48 Dan AKB48, https://afcofficial.wordpress.com/2012/08/31/jkt48-dan-akb48-koksama/ diakses 14/3/2019). Tidak puas dengan Sister Group yang di Jepang, lalu Akimoto mencoba bereksperimen dengan membentuk Sister Group di luar Jepang. Akimoto memulai project Sister Group pertama di luar Jepang dan negara yang beruntung adalah Indonesia.

JKT48 (Jakarta48) adalah grup idola yang termasuk dalam kerajaan Idol Grup 48 Akimoto Yasushi yang berbasis di Jakarta, Indonesia. Mereka adalah Sister Group resmi 
pertama AKB48 yang berada di luar Jepang. Proyek JKT48 ini dilaksanakan oleh Dentsu Media Group Indonesia dan MNC Group, dengan pengawasan dari produser Akimoto Yasushi. Single debut pertama mereka berjudul 'RIVER'. JKT48 lahir pada tanggal 17 Desember 2011. Teater mereka terletak di lantai 4 fX Sudirman, Jakarta Pusat. Perusahaan Dentsu telah membeli lisensi kepada Akimoto Yasushi untuk mendirikan JKT48 di Indonesia. Manajemen mereka diatur oleh JKT48 Project di bawah manajemen Akimoto Yasushi.

\section{Perbincangan Korean Wave dan Cool Japan di Media Sosial Twitter}

Selain media online, media sosial juga tengah berkembang dengan sangat pesat diseluruh belahan dunia, tidak terkecuali di Indonesia. Meminjam salah satu klasifikasi media sosial menurut Kaplan dan Haenlein yakni social networking site atau dapat disebut sebagai situs komunikasi sosial (Kaplan, 2010). Situs yang paling umum untuk jenis ini adalah Facebook, Twitter, MySpace, LinkedIn, Instagram, Path dan lain sebagainya. Sehingga dapat disimpulkan bahwa media sosial merupakan salah satu bentuk perkembangan dari adanya internet.

Dengan adanya internet, melalui media sosial seseorang dapat dengan mudah membagikan segala macam informasi, dan berkomunikasi dengan sesame perngguna media sosial. Kemudahan dalam membagikan informasi membuat media sosial kini tidak hanya diguakan dalam lingup yang sempit. Namun media sosial juga kerap digunakan sebagai wadah untuk mensosialisasikan sebuah kebijakan, pemasaran produk, bahkan media sosial juga dimanfaatkan untuk kepentingan politis dalam pemilihan umum.

Salah satu contoh layanan media sosial yang ramai digunakan masyarakat Indonesia yakni Twitter. Twitter adalah salah satu layanan social networking yang termasuk dalam kategori microblogging, atau ngeblog singkat dalam satu paragraph. Twitter menjadi jejaring sosial yang banyak digunakan untuk berbagi berita atau informasi secara cepat. Bahkan berdasarkan sebuah penelitian yang dilakukan oleh beberapa peneliti dari University of Edinburg jurusan School of Informatics menyatakan, untuk urusan pemberitaan yang detail, newswire masih menjadi 'raja' namun Twitter 
dalam hal ini bertindak sebagai penyampai berita atau informasi singkat ke semua pihak secara cepat.

Keefektifan dari media sosial twitter ini yang kemudian akan digunakan oleh peneliti untuk melihat bagaimana perbincangan seputar Korean Wave dan Cool Japan di media sosial twitter. Pemantauan perbincangan netizen ini bertujuan untuk melihat bagaimana antusiasme mereka yang memiliki kesamaan minat atau hobi dan menuangkannya dalam media sosial. Pemantauan cuitan dari netizen diperoleh dari sebuah sistem Artificial Intelligent yang disebut IPA (Index Perception Analysts) dengan menggunakan keyword sebagai kata kunci pencarian.

\section{Pantauan Twitter Seputar Korean Wave}

Untuk Korean Wave menggunakan keyword Korean Wave, Hallyu, Drama Korea, K Pop, Korean Pop, Pop Korea, Musik Korea, dan Korean Style. Berdasarkan pemantauan sepanjang Januari hingga Desember tahun 2017, terdapat total 20.006 cuitan netizen di media sosial twitter yang membicarakan seputar Korean Wave.

Gambar 2

Total Cuitan Netizen Indonesia Seputar Korean Wave

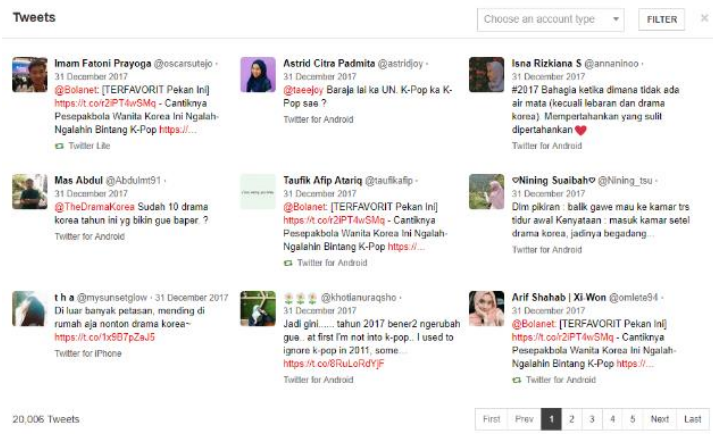

Secara keseluruhan, perbincangan netizen didominasi aktivitas membagikan informasi kegiatan seputar minat atau hobi mereka sebagai pencinta Korean wave. Mulai dari menonton drama korea, menikmati musik Korea, sampai check in ditempat-tempat 
yang menyediakan makanan dan minuman yang berbau Korea. Perbincangan seputar drama korea terpantau sebanyak 12.760 cuitan, atau 63.78 persen.

Gambar 3

Sebaran Netizen Indonesia Seputar Korean Wave

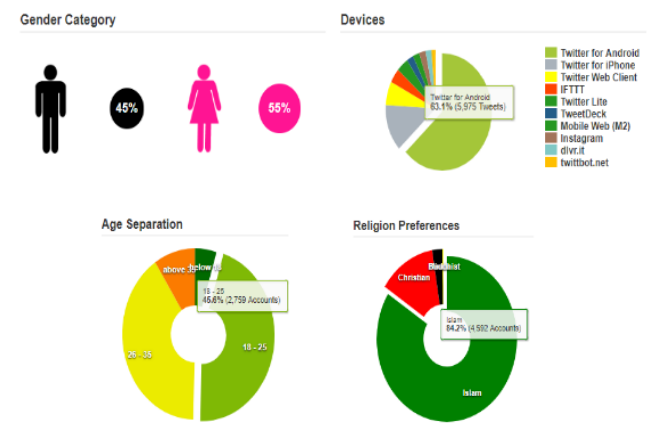

Data sebaran demografi netizen diambil dari pengisian profil yang dilakukan oleh netizen saat melakukan pendaftaran akun. Mulai dari tanggal dan tahun lahir, jenis kelamin, dan juga agama. Selain itu, sistem ini juga dapat mengetahui demografi netizen dari caption atau diksi Bahasa yang digunakan saat mengunggah cuitan. Berdasarkan data di atas, terdapat total 6.594 akun yang membicarakan seputar Korean Wave sepanjang tahun 2017, dengan detail sebagai berikut.

- Gender Category netizen lebih didominasi oleh akun perempuan dengan total 3.656 akun dibandingkan akun laki-laki yang hanya 2.928 akun atau sebesar 45 persen.

- Device terdapat total 10 perangkat yang digunakan oleh netizen untuk memposting seputar Korean Wave. Netizen terpantau lebih banyak menggunakan perangkat twitter for android dengan total 5.975 tweets atau sebesar 63.1 persen.

- Age Saparation netizen berusia 18-25 tahun mendominasi unggahan seputar Korean Wave dengan total 2.759 akun atau sebesar 45.6 persen. Sedangkan netizen rentang usia 26-35 tahun tercatat sebanyak 2.447 akun.

- Religion Preferences netizen beragama Islam mendominasi perbincangan seputar Korean Wave dengan total 4.592 akun atau sebesar 84.2 persen. Kemudian netizen beragama Kristen dengan total 723 akun.

Gambar 4

Text Analisis Seputar Korean Wave 


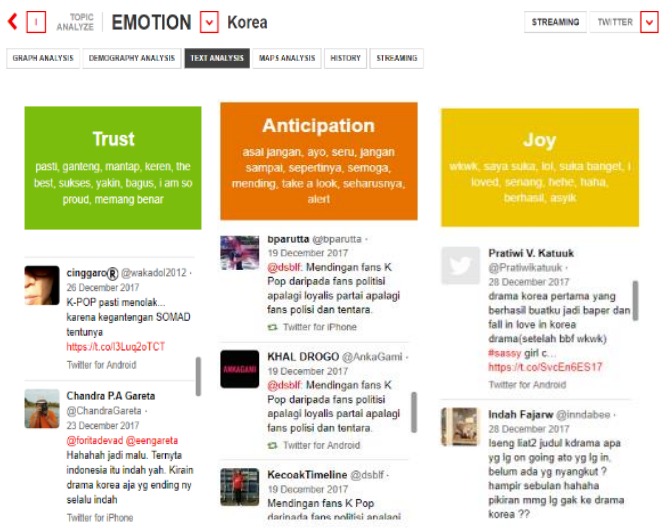

Dari data di atas dapat kita lihat sampel cuitan netizen yang dikategorikan berdasarkan diksi caption yang dituliskan. Pada emosi Trust kata-kata seperti pasti, ganteng, mantap, keren, the best, sukses, bagus, I am so proud dan memang benar sering digunakan oleh netizen. Pada unggahan dengan emosi Anticipation kata yang sering digunakan yaitu asal jangan, ayo, seru, jangan sampai, sepertinya, semoga, mending, take a look, seharusnya, dan alert. Sedangkan cuitan dengan emosi Joy didominasi diksi kata wkwk, saya suka, lol, suka banget, I loved, senang, hehe, haha, berhasil dan asik.

\section{Pantauan Twitter Seputar Cool Japan}

Untuk Cool Japan keyword yang digunakan adalah Cool Japan, Anime, Manga, Harajuku, Drama Jepang, J pop, Japan Pop, Jepang Pop, Musik Jepang, Cosplay dan Japan Style. Berdasarkan pemantauan sepanjang Januari hingga Desember tahun 2017, terdapat total 21.379 cuitan netizen di media sosial twitter yang membicarakan seputar Cool Japan.

Gambar 5

Total Cuitan Netizen Indonesia Seputar Cool Japan

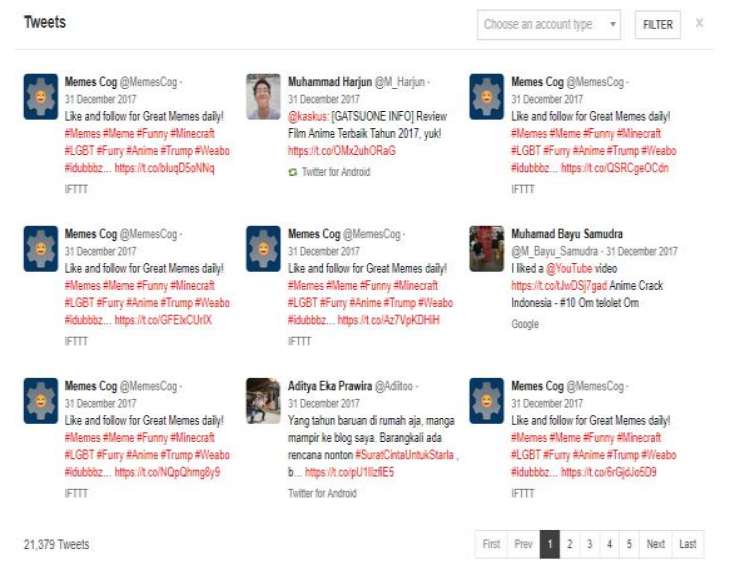


Secara keseluruhan, perbincangan netizen didominasi aktivitas membagikan informasi kegiatan seputar minat atau hobi mereka sebagai pencinta Cool Japan. Netizen yang membicarakan anime terpantau lebih dominasn dengan total 10.893 cuitan, kemudian perbincangan seputar Cosplay tercatat sebanyak 6.167 cuitan.

\section{Gambar 6}

Sebaran Netizen Indonesia Seputar Cool Japan
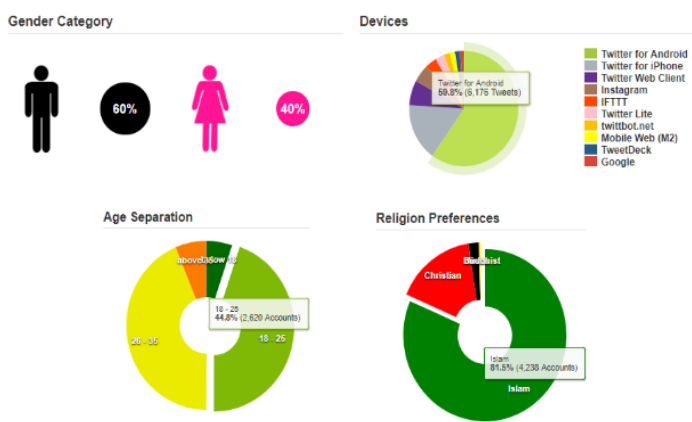

Data sebaran demografi netizen diambil dari pengisian profil yang dilakukan oleh netizen saat melakukan pendaftaran akun. Mulai dari tanggal dan tahun lahir, jenis kelamin, dan juga agama. Selain itu, sistem ini juga dapat mengetahui demografi netizen dari caption atau diksi Bahasa yang digunakan saat mengunggah cuitan. Berdasarkan data di atas, terdapat total 6.144 akun yang membicarakan seputar Cool Japan sepanjang tahun 2017, dengan detail sebagai berikut.

- Gender Category netizen lebih didominasi oleh akun perempuan dengan total 3.668 akun dibandingkan akun laki-laki yang hanya 2.476 akun atau sebesar 40 persen.

- Device terdapat total 10 perangkat yang digunakan oleh netizen untuk memposting seputar Cool Japan. Netizen terpantau lebih banyak menggunakan perangkat twitter for android dengan total 6.176 tweets atau sebesar 59.8 persen.

- Age Saparation netizen berusia 18-25 tahun mendominasi unggahan seputar Korean Wave dengan total 2.620 akun atau sebesar 44.8 persen. Sedangkan netizen rentang usia 26-35 tahun tercatat sebanyak 2.552 akun. 
- Religion Preferences netizen beragama Islam mendominasi perbincangan seputar Korean Wave dengan total 4.238 akun atau sebesar 81.5 persen. Kemudian netizen beragama Kristen dengan total 835 akun.

\section{Gambar 7}

Text Analisis Seputar Cool Japan

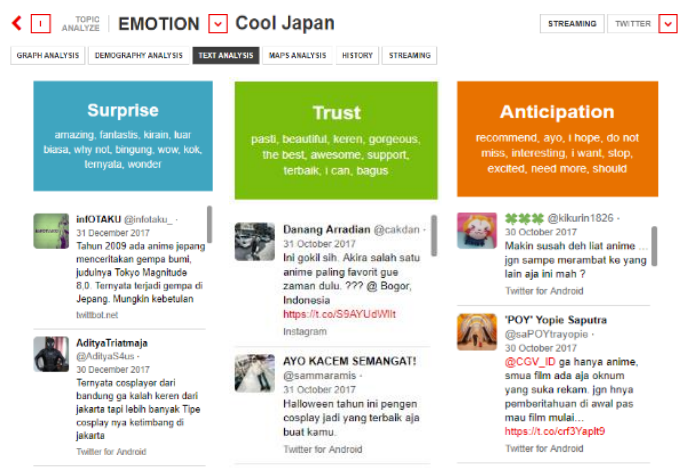

Dari data di atas dapat kita lihat sampel cuitan netizen yang dikategorikan berdasarkan diksi caption yang dituliskan. Pada emosi Surprise kata-kata seperti amazing, fantastis, kirain, luar biasa, why not, bingung, wow, kok, ternyata, dan wonder sering digunakan oleh netizen. Pada unggahan dengan emosi Trust kata yang sering digunakan yaitu pasti, beautiful, keren, gorgeous, the best, awesome, support, terbaik, I can, dan bagus. Sedangkan cuitan dengan emosi Anticipation didominasi diksi kata recommend, ayo, I hope, do not, miss, interesting, I want, stop, excited, need more dan should.

\section{Indikator Perbandingan Strategi Multi-Track Diplomacy Korea Selatan dan Jepang}

Kebangkitan ekonomi Korea Selatan dan Jepang tidak terlepas dari semakin populernya sektor entertaiment atau industri kedua negara. Korea Selatan dengan $K$-Pop dan K-Drama, sedangkan Jepang lebih dikenal dengan Manga dan Anime. Kedua negara tersebut sama-sama mendukung penuh pengembangan dunia hiburan yang kemudia dijadikan sebagai 'alat' diplomasi untuk mengenalkan budaya dari masing-masing negara. Upaya tersebut terhitung sangat efektif dan efisien dalam upaya mendatangkan keuntungan bagi sektor perekonomian Korea Selatan dan Jepang. Berikut akan penulis 
jabarkan dalam bentuk tabel mengenai perbandingan strategi multi-track diplomacy Korea Selatan dan Jepang.

Dapat Disimpulkan bahwa Korea Selatan lebih siap dalam diplomasi budayanya. Dapat dilihat dari besarnya kucuran dana yang di berikan oleh pemerintah Korea Selatan untuk mendukung industri hiburan negaranya. Aktor non- pemerintah Korea Selatan juga banyak yang berperan aktif dalam membantu menyebarluaskan budaya mereka ke dunia internasional. Para aktor non-pemerintah tersebut menjadi garda terdepan bagi keberhasilan diplomasi budaya Korea Selatan.

Jadi, pemerintah Korea Selatan sangat mendukung industri hiburan negaranya dengan memberi dukungan modal. Lalu, para aktor non-pemerintahlah yang menjadi alat keberhasilan diplomasi budaya Korea Selatan sehingga mampu memberikan banyak keuntungan bagi negaranya, dan telah berhasil mempengaruhi kebudayaan negara lain. Korea selatan sangat fokus terhadap kebutuhan dalam negerinya, karena hal itu akan berdampak positif bagi kemajuan negaranya.

\section{KESIMPULAN}

Pemerintah Korea Selatan dan Jepang Nampak sangat serius dalam mendukung industri Pop Culture dari masing-masing negara. Dalam upaya meningkatkan kualitas pekerja seni di Korea Selatan, Pemerintah Korea Selatan terus memberikan beasiswa kepada pekerja seni untuk dapat menempuh Pendidikan di Amerika dan menerapkan apa yang mereka dapat saat kembali ke Korea Selatan. Disisi lain, Pemerintah Korea Selatan juga aktif dalam menjalin kerja sama dengan pihak swasta untuk mengembangkan kualitas industri entertaimen di Korea Selatan.

Sementara itu, kebijakan Cool Japan menjadi sebuah proyek pemerintah yang memiliki tujuan untuk meningkatkan kesan positif terhadap Jepang melalui promosi kebudayaan, perdagangan dan pariwisata. Jika sebelumnya pemerintah Jepang masih enggah untuk memanfaatkan keberadaan Pop Culture yang lebih kepada budaya modern, namun kini pemerintah Jepang justru mengandalkan keberadaan anime, manga, drama, dan musik sebagai pondasi pemasaran kebudayaan tradisional Jepang. 
Hal tersebut dapat dilihat dari banyaknya tayangan anime Jepang yang turut memuat kebudayaan tradisional masyarakat Jepang, mulai dari minum teh dan juga pemandian air panas. Selain itu, sejumlah makanan khas Jepang juga kerap muncul dalam tayangan anime, mulai dari ramen, dorayaki, dan sushi. Bahkan pada film animasi Cars 2 produksi Pixar Animation Studios for Walt Disney Picture juga menampilkan setting tempat di Kota Tokyo, lengkap dengan kebudayaan menanam padi, sampai makanan tradisionalnya juga turut di 'kampanyekan' dalam Cars 2.

Korea Selatan lebih siap dalam diplomasi budayanya. Dapat dilihat dari besarnya kucuran dana yang di berikan oleh pemerintah Korea Selatan untuk mendukung industri hiburan negaranya. Aktor non-pemerintah Korea Selatan juga banyak yang berperan aktif dalam membantu menyebarluaskan budaya mereka ke dunia internasional. Para aktor non-pemerintah tersebut menjadi garda terdepan bagi keberhasilan diplomasi budaya Korea Selatan.

Jadi, pemerintah Korea Selatan sangat mendukung industri hiburan negaranya dengan memberi dukungan modal. Lalu, para aktor non-pemerintahlah yang menjadi alat keberhasilan diplomasi budaya Korea Selatan sehingga mampu memberikan banyak keuntungan bagi negaranya, dan telah berhasil mempengaruhi kebudayaan negara lain. Korea selatan sangat fokus terhadap kebutuhan dalam negerinya, karena hal itu akan berdampak positif bagi kemajuan negaranya.

Selain itu, adanya perbedaan tahun ketenaran dari Korean Wave dan Cool Japan. Jepang lebih dulu memasarkan industri hiburannya, yaitu sekitar tahun 1990an hingga 2000an awal. Yang kita ketahui bahwa pada tahun tersebut teknologi media belum secanggih sekarang ini atau ketika era kejayaan Korean Wave. Ketenaran Korean Wave dipengaruhi dan didukung oleh teknologi media yang sudah modern atau lebih canggih, sehingga dengan mudah disebarluaskan ke banyak negara.

\section{DAFTAR PUSTAKA}

\section{Buku}


Aziz, A. A. (2013). Hallyu: Sarana Peningkatan Daya Tarik Korea. Dalam Budaya Hallyu Korea. Yogyakarta: INAKOS (The International Association of Korean Studies in Indonesia) Pusat Studi Korea Universitas Gadjah Mada.

Diamond, Louise and Mc Donald, John. (1996) Multi-Track Diplomacy : A System Approach to Peace - Third Edition. United States of America: Kumarian press.

Ibrahim, Idi Subandy. (2007). Budaya Populer Sebagai Komunikasi. Yogyakarta: Jalasutra.

Leonard, Mark., Stead, Catherine., and Smewing, Conrad. (2002). Public Diplomacy. London: The Foreign Policy Centre.

Raditya, D. (2013). Hallyu, Citra Korea Di Mancanegara. Dalam Budaya Hallyu Korea. Yogyakarta: INAKOS (The International Association of Korean Studies in Indonesia) Pusat Studi Korea Universitas Gadjah Mada.

Wibowo, W. (2013). K-Drama, Industri Kreatif Berbasis Budaya Populer. Dalam Budaya Hallyu Korea. Yogyakarta: INAKOS (The International Association of Korean Studies in Indonesia) Pusat Studi Korea Universitas Gadjah Mada.

Yudhantara, R. L. (2010). Korean Wave (Hallyu) Sebagai Soft Diplomasi Korea Selatan. Dalam Politik dan Pemerintahan Korea. Yogyakarta: INAKOS (The International Association of Korean Studies in Indonesia) Pusat Studi Korea Universitas Gadjah Mada.

\section{Publikasi Elektronik}

Aso, T. (2006). "A new look at cultural diplomacy: A call to Japan's cultural practitioners". Diakses dari http://mofa.go.jp/announce/fm/aso/speech0406-2.html pada tanggal 29 Juli 2018.

CNBN. (2014). "Korea Builds on Next Wave of Hallyu". Diakses dari http://www.cnbn.com/2014/08/27/korea-builds-on-next-wave-of-hallyu.html pada tanggal 27 Juli 2018.

Culture and Globalization. Diakses dari http://www.globalization101.org/uploads/File/Culture/cultall2010.pdf pada tanggal 31 Maret 2018.

Fukase, Atsuko. "Tokyo Launches Cool Japan Investment Fund". Wall Street Journal. Diakses dari http://blogs.wsj.com/japanrealtime/2013/11/18/tokyo-launches-cool-japan-investmentfund/ pada tanggal 8 Maret 2019.

Index Perception Analysts www.ipaebdesk.co.id

Japanese Station. Halaman 84. Diakses dari https://books.google.co.id pada tanggal 28 Juli 2018. McGray, Douglas. (2009). “Japan's Gross National Cool”. Foreign Policy, 1 Mei 2002. Diakses dari http://foreignpolicy.com/2009/11/11/japans-gross-national-cool pada tanggal 27 Juli 2018.

Mori, Y. (2000). "The general policy speech to the 150th session of Diet". Diakses dari http://www.kantei.go.jp/jp/morisouri/mori_speech/2000/0921syosin.html pada tanggal 29 Juli 2018. 


\section{Global Insight Journal}

Vol 04, No. 02

April - September 2019

ISSN 2541-318X

St. Michel, Patrick. "Japan's Ministry of Cool". The Atlantic, 19 Maret 2015. Diakses dari http://www.theatlantic.com/entertainment/archive/2015/3/japan-and-the-power-ofcoolness/387664/ pada tanggal 8 Maret 2019.

The Korean Times. (2013). "Eximbank to Finance 'Hallyu' Businesses". Diakses dari http://koreantimes.co.kr/www/news/biz/2013/02/602_130133.html pada tanggal 20 Juli 2018.

\section{Artikel Jurnal}

S Rana, Kishan. (2011). 21st Century Diplomacy A Practitioner"s Guide Key: Studies in Diplomacy. Lorna Lloyd. Series Editor.

Shin, Gi-Wook. (2003). "The Paradox of Korean Globalization". Asia/Pasific Research Center, Susanthi, N. L. (2011). Gurita Budaya Populer Korea di Indonesia. 